\title{
PENGKAJIAN MUTU PRODUK VITAMIN D3 SIRUP DI PT.PYRIDAM FARMA Tbk. TERHADAP PENINGKATAN KUALITAS KESEHATAN
} Okta Alia dan Rida Emelia

Politeknik Piksi Ganesha Bandung, Indonesia

E-mail: oktaalia502@gmail.com dan emeliarida1310@gmail.com

\section{Diterima:}

14 Oktober 2021

Direvisi:

15 Oktober 2021

Disetujui:

15 Oktober 2021

\section{Abstrak}

Kebutuhan Vitamin D3 saat ini sangat berperan penting untuk menjaga daya tahan tubuh agar tetap baik pada masa pandemic atau memasuki era New normal seperti saat ini, berperan untuk menjaga dan meningkatkan imunitas tubuh menjadi lebih kuat terhadap paparan virus penyakit. Kekurangan Vitamin D3 dalam tubuh dapat menyebabkan tubuh menjadi mudah terinfeksi sumber penyakit. Vitamin D3 dapat di peroleh dari paparan sinar matahari pagi, namun pada masa pandemic saat ini sebagian individu harus melakukan isolasi sehingga mengalami keterbatasan ruang gerak. Penelitian dilakukan di industri Farmasi dengan tujuan Mengetahui bagaimana Pemastian Mutu Produk Vitamin D3 Syr di PT.Pyridam Farma dan Memahami Pengkajian Mutu Produk Sesuai dengan CPOB. Metode penelitian dilakukan secara deskriptif dengan pengambilan data prospektif observasional. Pemastian mutu produk (PMP) dikenal dengan istilah lain Produk Quality Review adalah evaluasi yang dilakukan secara berkala dari semua produk obat farmasi terdaftar maupun produk eksport, dengan tujuan melihat kekonsistensian formulasi, proses pembuatan, hasil evaluasi harus Memenuhi Syarat seperti, pengujian organoleptic, $\mathrm{pH}$, viscositas, Bobot Jenis, kadar zat aktif, evektifitas pengawet dan pegujian mikrobiologi. Dokumentasi penggunaaan bahan awal, bahan kemas primer - sekunder. Produksi Vitamin D3 syr di PT.Pyridam farma Tbk. Saat ini dilakukan secara konsisten dari berbagai aspek baik pada formulasi tidak ada perubahan, penggunaan bahan awal, kemas primer dan sekunder tidak ada perubahan produsen maupun penyalur, proses produksi tervalidasi dan konsisten, evaluasi sediaan memenuhi persyaratan yang di tetapkan, dan tidak adanya laporan penyimpangan, laporan produk penarikan atau produk di kembalikan. Produksi Vitamin D3 Syr Memenuhi Syarat dalam berbagai aspek hingga dapat menjamin produk memiliki kualitas yang baik.

Kata kunci: Kualitas kesehatan, Mutu produk dan Vitamin D3

\section{Abstract}

The need for Vitamin D3 is currently very important to maintain the body's endurance to remain either in the pandemic period or enter the New Normal era as it is today, playing a role to maintain and increase the body's immunity to be stronger against exposure to disease viruses. Vitamin D3 deficiency in the body can cause the body to become easily infected with the source of the disease. Vitamin D3 can be obtained from exposure 
Keywords: Quality of health, Product Quality and Vitamin D3

\section{Pendahuluan}

Industri farmasi memiliki fungsi pembuatan obat dan atau bahan obat, pendidikan dan pelatihan, serta penelitian dan pengembangan (Octaviani \& Muhaida, 2017). Industri farmasi yang memproduksi obat dapat mendistribusikan atau menyalurkan hasil produksinya langsung kepada pedagang besar farmasi, apotek, instalasi farmasi rumah sakit, pusat kesehatan masyarakat, klinik, dan toko obat sesuai dengan ketentuan peraturan perundang-undangan (Santi, 2015). Sedangkan industri farmasi yang menghasilkan bahan obat dapat mendistribusikan atau menyalurkan hasil produksinya langsung kepada pedagang besar bahan baku farmasi dan instalasi farmasi rumah sakit sesuai dengan ketentuan peraturan perundang-undangan (Santi, 2015). Industri farmasi dapat melakukan kegiatan proses pembuatan obat dan atau bahan obat untuk semua tahapan dan atau sebagian tahapan. Setiap pendirian industri farmasi wajib memperoleh izin industri farmasi dari Direktur Jendral Pembinaan Kefarmasian dan Alat Kesehatan Menteri Kesehatan RI (Purwaningsih, Yuliwulandari, Soenyono, \& Santoso, 2019).

Industri farmasi wajib memenuhi persyaratan CPOB sesuai dengan ketentuan Keputusan Menteri Kesehatan No.43/Menkes/SK/II/1998. Industri farmasi wajib mempekerjakan sekurang-kurangnya dua orang apoteker warga negara Indonesia, satu sebagai sebagai penangung jawab produksi dan lainnya sebagai penangung jawab mutu. Industri farmasi yang telah memenuhi persyaratan CPOB diberikan sertifikat 
CPOB. Industri farmasi hendaklah memiliki personil yang terkualifikasi dan berpengalaman praktis dalam jumlah yang memadai (Amalia, 2018). Tiap personil tidak dibebani tanggung jawab yang berlebihan untuk menghindari resiko terhadap mutu obat (Irfiani, Pradana, \& Winantari, 2018). Industri farmasi harus memiliki struktur organisasi. Tugas spesifik dan kewenangan dari personil pada posisi penanggungjawab hendaklah dicantumkan dalam uraian tugas tertulis (Kodri, Una, \& Zaki, 2020).

Industri farmasi hendaklah memberikan pelatihan bagi seluruh personil yang bertugas di area produksi, gudang penyimpanan dan laboratorium (termasuk personil teknik, perawatan dan petugas kebersihan) (Astuti, 2020). Di samping pelatihan dasar dalam teori dan praktek CPOB, personil baru hendaklah mendapatkan pelatihan sesuai dengan tugas yang diberikan. Pelatihan berkesinambungan hendaklah diberikan dan efektifitas penerapannya, dinilai secara berkala. Hendaklah tersediaprogram pelatihan yang disetujui kepala bagian masing-masing. Merujuk saran dari para ahli kesehatan di dunia maupun di Indonesia salah satu terapi yang di berikan untuk menguatkan atau memperbaiki imunitas tubuh yang kurang baik di anjurkan untuk mengkonsumsi vitamin D3 kepada pasien yang terpapar virus Covid-19 dan di sarankan bagi masyarakat luas untuk juga mengkonsusmi suplemen/ vitamin tambahan sebagai upaya meningkatkan imunitas tubuh di antaranya ialah dengan konsumsi Vitamin D3 (Dewi \& Ners, 2015).

Dampaknya, permintaan akan kebutuhan vitamin D3 semakin meningkat terhadap produsen. Paparan sinar matahari merupakan sumber vitamin D3 yang paling baik, dan tidak ditemukan kasus intoksikasi vitamin D3 yang di akibatkan oleh terpaparnya sinar matahari berlebihan (Handono et al., 2018). Sebagian besar orang dapat memenuhi kebutuhan vitamin D3 melalui paparan sinar matahari karena vitamin D3 dapat dihasilkan secara endogen, saat sinar ultraviolet B mengenai kulit yang memicu terjadinya sintesis vitamin D3 (Rimahardika, Subagio, \& Wijayanti, 2017). Terlebih Orang yang bekerja di dalam ruangan kemungkinan dapat mengalami defisiensi vitamin D3 karena bekerja di dalam ruangan tidak terkena paparan sinar matahari dengan baik (Saptarini, 2019). Begitupun di masa pandemic seperti saat ini, dimana keterbatasan ruang terbuka bagi pasien COVID-19 dengan gejala ringan, terlebih bagi pasien dengan gejala berat yang harus melakukan isolasi di dalam ruangan mengakibatkan kesulitan dalam mendapatkan paparan sinar matahari sebagai sarana produksi vitamin $\mathrm{D}$, sementara bagi pasien COVID-19 peranan vitamin D3 sangatlah di perlukan bagi proses kesembuhan dan pemulihan, yang mana Penelitian dari University of Cantabria di Santander, Spanyol, Jose L Harnandez seperti di kutip dari Health Line mengatakan, pengobatan vitamin D3 harus di rekomendasikan pada pasien COVID-19 dengan kadar vitamin D3 rendah karena mungkin memiliki efek menguntungkan baik pada musculoskeletal maupun system kekebalannya (Novita Sari, 2021).

Faktor penyebab kurangnya vitamin D3 salah satunya kekurangan paparan sinar matahari (UVB), kurangnya aktivitas diluar ruangan, gaya hidup yang cenderung menghindari sinar matahari, penggunaan sunblock, rendahnya asupan makanan kaya vitamin D3 seperti susu dan makanan yang difortifikasi, adanya kecenderungan mengurangi bahan makanan tinggi lemak yang pada akhirnya mengakibatkan rendahnya asupan vitamin D3 serta bekerja di dalam ruangan dalam jangka waktu yang panjang Vitamin D3 adalah vitamin yang larut dalam lemak dan mengandung struktur molekul steroid yang dibutuhkan untuk berbagai proses metabolisme. Tujuan penelitian ini adalah untuk mengetahui bagaimana Pemastian Mutu Produk Vitamin D3 di PT.Pyridam Farma. Penelitian ini diharapkan berguna untuk menambah pengetahuan dan wawasan dalam Pengkajian Mutu Produk Vitamin D3 baik bagi penulis, tenaga medis di pelayanan, edukasi terhadap pasien serta masyarakat umum. 


\section{Metode Penelitian}

Penelitian ini merupakan penelitian deskriptif dengan pengambilan data secara prospektif observasional. Penelitian deskriptif adalah penelitian yang bertujuan untuk melakukan deskripsi mengenai fenomena yang ditemukan, baik yang berupa faktor risiko maupun efek atau hasil dan prosepektif observasional adalah pengambilan data/ pengamatan secara langsung (HR, 2018).

Teknik pengambilan data untuk menilai mutu dari pengkajian produk Vitamin D3 dilakukan melalui observasi sesuai standar COPB. Pengambilan data dilakukan dengan mengambil 12 sampel dari proses produksi yang dipilih secara berurutan sesuai tahun dan bulan berjalan kemudian mengisi tabel mutu indicator hasil dari catatan proses produksi dan pengujian sediaan produk Vitamin D3 Syr. Selanjutnya data dari setiap indikator mutu seperti pemerian sediaan, kadar zat aktif pemerikasaan Berat Jenis, $\mathrm{pH}$, Pemeriksaan viskositas, waktu proses olah, penggunaan bahan kemas primer dan sekunder, diolah dan di bandingkan dengan nilai standar atau syarat masing masing indikator mutu tersebut.

\section{Hasil dan Pembahasan}

Penelitian mengenai Pemastian Mutu Produk Vitamin D3 Syr dilakukan di departemen Quality Assurance (QA) PT. Pyridam farma Tbk. Data di ambil dari 12 Batch No berurutan Produk D3 Syr pada periode tahun produksi 2020 - 2021. Penelitian ini bertujuaan untuk mengetahui gambaran mutu produk Vitamin D3 syr di PT.Pyridam Farma Tbk. Apakah produk di produksi sesuai dengan standar CPOB serta pengujian hasil dari sediaan memenuhi spesifikasi standar mutu yang telah di tetapkan dengan hasil memenuhi persyaratan uji berdasarkan Farmakope.

Mutu atau kualitas adalah kepatuhan terhadap standar yang telah ditetapkan atau sesuai dengan persyaratan (Sabarudin, Suryani, \& Nazir, 2016). Pemastian mutu produk yang dilakukan secara berkala pada Industri Farmasi sangat penting karena merupakan tolak ukur produk yang dapat terdistribusi dengan baik serta menjamin khasiat maksimal yang di harapkan konsumen (Suhelayanti et al., 2020). Pemastian Mutu Produk pada produk Vitamin D3 Syr di PT.Pyridam Farma Tbk. Meliputi data :

1. Data Formulasi yang di gunakan

2. Hasil pengujian Organoleptik (Pemerian, rasa, bentuk, warna)

3. Pemeriksaan kadar zat aktif dan uji pengawet

4. Pemeriksaan Berat Jenis \& $\mathrm{pH}$

5. Pemeriksaan Viskositas \& Volumen terpindahkan

6. Pemeriksaan Mikrobiologi

7. Penggunaan Bahan Awal Zat Aktif \& Zat Tambahan (Mencantumkan No QC/ No pemeriksaan, mencantumkan nama Industri pembuat dan nama distributor)

8. Mencantumkan Dokumentasi Suhu \& Kelembapan ruangan yang di gunakan selama proses (Pembuatan Syr ;Penimbangan, pencampuran, strerilisasi botol, pengisian sediaan kedalam botol)

9. Dokumentasi waktu proses

10. Dokumentasi rekonsiliasi hasil proses

11. Penggunaan Bahan kemas primer dan sekunder (Mencantumkan No QC/ No pemeriksaan , mencantumkan nama Industri pembuat dan nama distributor)

12. Data Stabilitas

13. Data Penyimpangan (Jika ada) 
Pemastian Mutu Produk merupakan satu di antara penerapan aspek pada management mutu yang di atur dalam CPOB 2018. Pemastian mutu produk (PMP)/ Produck Quality Review adalah evaluasi yang dilakukan secara berkala dari semua produk obat farmasi terdaftar maupun produk eksport, dengan tujuan melihat kekonsistensian proses, hasil pemeriksaan sesuai spesifikasi, dokumentasi penggunaaan bahan awal maupun bahan kemas primer - sekunder serta sebagai bahan evaluasi terhadap produk jadi. Pemastian Mutu Produk (PMP) umumnya yang di lakukan oleh PT.Pyridam Farma Tbk. Yang merupakan komitmen perusahaan dalam menjaga, mengembangkan dan perbaikan mutu produk untuk semakin baik dalam berbagai aspek sebagai jaminan produk dapat di gunakan dalam keadaan baik dan kualitas terjaga terhadap konsumen.

Vitamin D3 Syr termasuk kedalam golongan suplemen yang di produksi di gedung 2 (NBL 2/ Non Beta Laktam 2), dimana merupakan gedung dengan vasilitas produksi Non Streril sediaan liquid. Setiap Industry Farmasi berbeda-beda dalam penerapan dan pembuatan laporan Pengkajian Mutu Produk. Di PT.Pyridam Farma Tbk. Pembuatan laporan Pemastian Mutu Produk setiap produk hendaknya di lakukan minimal 1 tahun dengan data yang di dapat dari catatan batch produksi/ Batch Record (BR) lengkap dengan laporan analisa, Coa Obat Jadi, serta data data pendukung lainya yang berkaitan dengan produk yang bersangkutan, dengan data terkumpul minimal 10 No Batch.. Jika dalam 1 tahun berjalan kurang dari 10 batch yang di produksi, maka total batch yang bisa di olah menjadi suatu laporan akan di gabungkan menjadi satu sehingga memenuhi persyaratan jumlah data batch no yang akan di olah menjadi suatu laporan

Di PT.Pyridam Farma Tbk. No Batch merupakan istilah lain sebagai identitas pada produk, atau disebut juga nomor bets. Pedoman Cara Pembuatan Obat yang Baik (CPOB) menyebut, batch atau bets adalah sejumlah obat yang mempunyai sifat dan mutu yang seragam yang dihasilkan dalam satu siklus pembuatan atas suatu perintah pembuatan tertentu.

Pada Periode Tahun 2020 - 2021 telah tercatat sebanyak 12 No batch di produksi produk Vitamin D3 Syr. Yang artinya dalam satu tahun berjalan telah di lakukan produksi terhadap produk Vitamin D3 Syr sebanyak 12 kali.

Metode yang di gunakan dalam penelitian observasi yaitu dengan data yang di dapat dari beberapa dokumen catatan batch produk Vitamin D3 Syr yang telah di lakukan di PT.Pyridam Farma Tbk. Selama periode Tahun 2020 - 2021. Data pendukung dalam penyusunan laporan Pemastian Mutu Produk di PT.Pyridam Farma Tbk :

1) Data penggunaan material bahan awal, kemas primer \& kemas sekunder

2) Petunjuk pembuatan dan pengemasan

3) Sejarah dokumentasi

4) Dokumentasi waktu proses

5) Catatan in process control

6) Prosedur analitik

7) Sertifikat analisis, mikrobiologi dan CoA obat jadi

8) Data stabilitas

9) Laporan penyimpangan kualitas

10) Complaints dan recall

11) Produk kembalian 
Pemastian Mutu Produk yang di lakukan di PT.Pyridam Farma di lakukan setalah produk dinyatakan Released oleh kepala Departemen Quality Assurancel QA Manager semua data akan di input dalam suatu system di Ms.Exel semua data akan di input untuk dikumpulkan sehingga dapat di olah menjadi suatu laporan. Berikut komponen susunan penyajian data terhadap Produk Vitamin D3 Syr yang dapat di peroleh:

1. Formulasi produk, material pendukung, proses/ waktu pembutan

2. Dokumen pendukung seperti data stabilitas, komplain dan recall, produk kembalian (Tidak dapat di tampilkan pada laporan ini)

3. Pengujian Fisika terhadap spesifikasi yang di tetapkan untuk Vitamin D3

\section{Uji Organoleptik}

Tabel 1. Uji Organoleptik Vitamin D3 Syr

\begin{tabular}{|c|c|c|c|}
\hline No. & No. Bets & Pemerian & Identifikasi \\
\hline & Syarat & $\begin{array}{l}\text { Sirup berwarna kuning } \\
\text { dengan rasa manis, } \\
\text { beraroma mangga dan } \\
\text { tidak terdapat } \\
\text { kontaminasi partikel } \\
\text { asing pada sirup tersebut. }\end{array}$ & $\begin{array}{l}\text { Waktu retensi puncak } \\
\text { utama yang dihasilkan } \\
\text { larutan uji sama dengan } \\
\text { larutan pembanding }\end{array}$ \\
\hline \multicolumn{4}{|c|}{ C2.1-RD-CPP178-00 } \\
\hline 1 & LT144 & Sesuai & Sesuai \\
\hline 2 & AB169 & Sesuai & Sesuai \\
\hline 3 & $\mathrm{AB} 170$ & Sesuai & Sesuai \\
\hline 4 & $\mathrm{AB} 171$ & Sesuai & Sesuai \\
\hline 5 & GB101 & Sesuai & Sesuai \\
\hline 6 & HB164 & Sesuai & Sesuai \\
\hline 7 & IB155 & Sesuai & Sesuai \\
\hline 8 & LB012 & Sesuai & Sesuai \\
\hline 9 & CK031 & Sesuai & Sesuai \\
\hline 10 & CK212 & Sesuai & Sesuai \\
\hline 11 & DK127 & Sesuai & Sesuai \\
\hline 12 & DK179 & Sesuai & Sesuai \\
\hline
\end{tabular}




\section{Pengujian Viscositas}

Tabel 2. Uji Viscositas Vitamin D3 Syr

\begin{tabular}{cc}
\hline $\begin{array}{c}\text { No } \\
\text { Batch }\end{array}$ & $\begin{array}{c}\text { Viskositas (cps) } \\
\text { Syarat : } \\
\text { 10 cps - 200 cps } \\
\text { (Spindle 61, Rpm 100) }\end{array}$ \\
\hline LT144 & 21,00 \\
\hline AB169 & 94,10 \\
\hline AB170 & 104,00 \\
\hline AB171 & 26,10 \\
\hline GB101 & 19,30 \\
\hline HB164 & 19,30 \\
\hline IB155 & 21,00 \\
\hline LB012 & 18,30 \\
\hline CK031 & 23,10 \\
\hline CK212 & 22,90 \\
\hline DK127 & 21,00 \\
\hline DK179 & 19,70 \\
\hline MIN & 18,30 \\
\hline MAX & 104,00 \\
\hline X & 34,15 \\
\hline
\end{tabular}

\section{Viscositas}

Syarat : 10 cps - 200 cps

(Spindle 61, rpm 100)

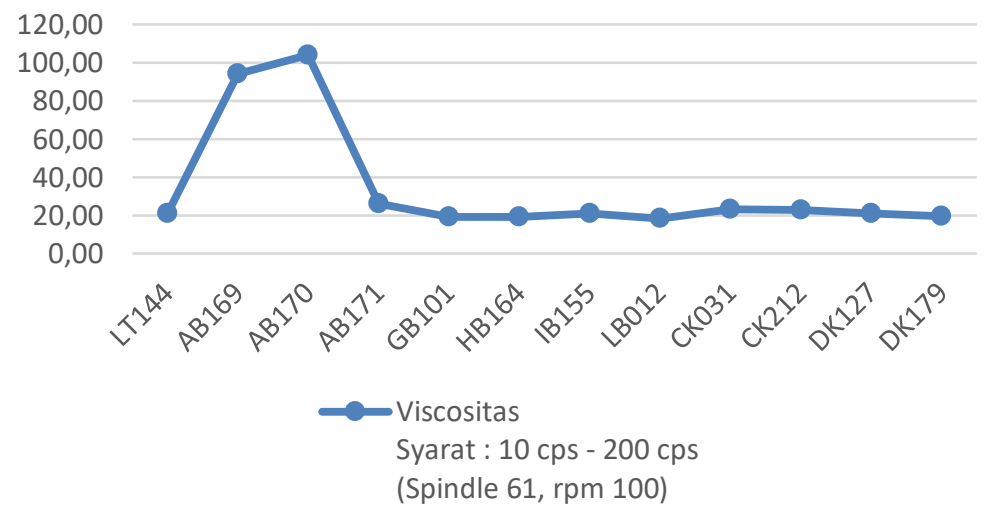

Diagram 1. Uji Viscositas Vitamin D3 Syr 


\section{Pengujian Berat Jenis (BJ)}

Tabel 3. Pengujian Berat Jenis

\begin{tabular}{cc}
\hline $\begin{array}{c}\text { No } \\
\text { Batch }\end{array}$ & Berat Jenis (BJ) \\
\hline LT144 & 1,06 \\
\hline AB169 & 1,06 \\
\hline AB170 & 1,06 \\
\hline AB171 & 1,06 \\
\hline GB101 & 1,06 \\
\hline HB164 & 1,06 \\
\hline IB155 & 1,06 \\
\hline LB012 & 1,06 \\
\hline CK031 & 1,08 \\
\hline CK212 & 1,06 \\
\hline DK127 & 1,07 \\
\hline DK179 & 1,06 \\
\hline MIN & 1,06 \\
\hline MAX & 1,08 \\
\hline X & 1,06 \\
\hline
\end{tabular}

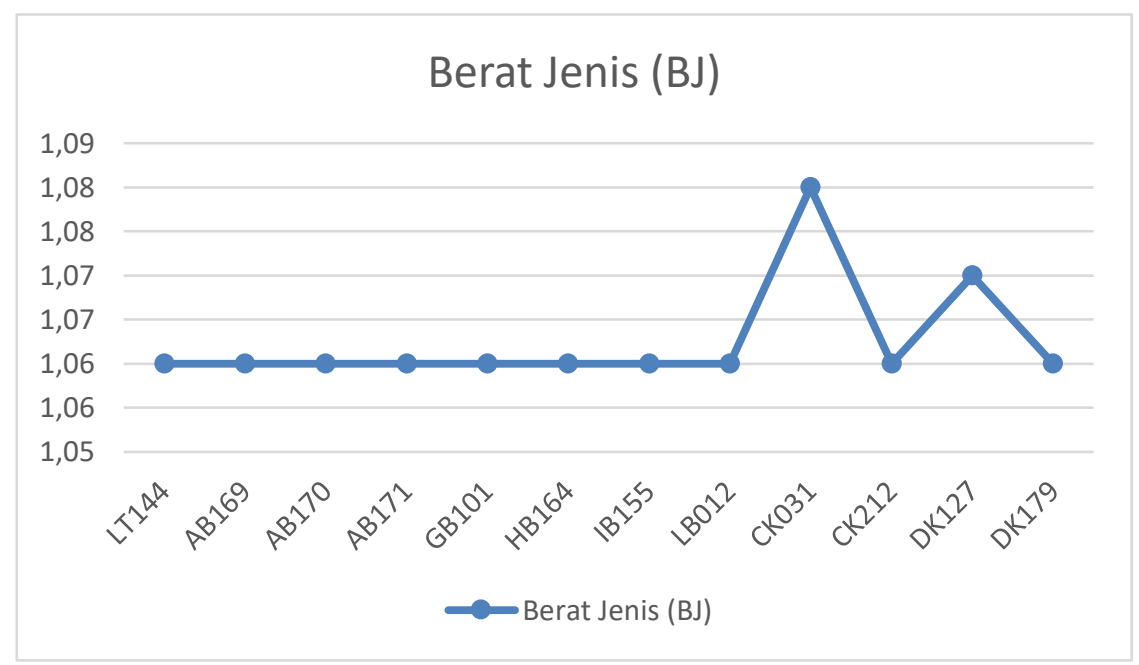

Diagram 2. Penujian Berat Jenis 


\section{Pengujian pH}

Tabel 4. Pengujian $\mathrm{pH}$

\begin{tabular}{cc}
\hline $\begin{array}{c}\text { No } \\
\text { Batch }\end{array}$ & $\begin{array}{c}\text { SH } \\
\text { Syarat } \mathbf{4 , 5 - 6 , 5}\end{array}$ \\
\hline LT144 & 5,25 \\
\hline AB169 & 5,33 \\
\hline AB170 & 5,36 \\
\hline AB171 & 5,35 \\
\hline GB101 & 5,76 \\
\hline HB164 & 5,49 \\
\hline IB155 & 5,46 \\
\hline LB012 & 5,63 \\
\hline CK031 & 5,28 \\
\hline CK212 & 5,30 \\
\hline DK127 & 5,55 \\
\hline DK179 & 5,46 \\
\hline MIN & 5,25 \\
\hline MAX & 5,76 \\
\hline$X$ & 5,44 \\
\hline
\end{tabular}

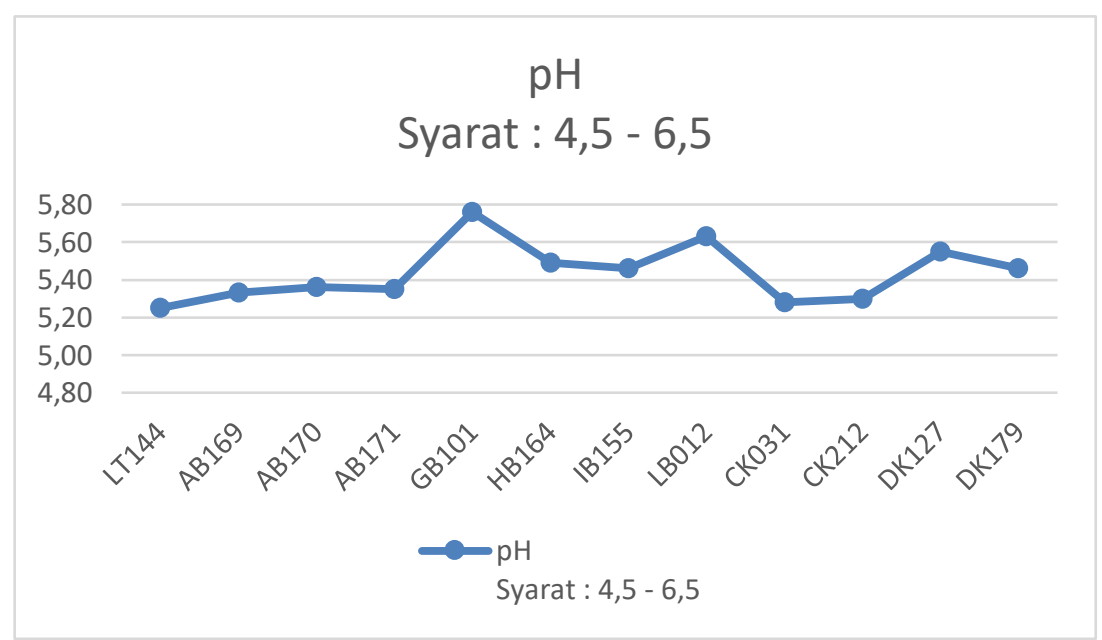

Diagram 3. Pengujian pH 


\section{Pengujian Mikrobiologi}

Tabel 5. Pengujian Mikroorganisme

\begin{tabular}{|c|c|c|c|c|c|c|c|c|}
\hline \multirow[b]{2}{*}{$\begin{array}{c}\text { No } \\
\text {. }\end{array}$} & \multirow[b]{2}{*}{$\begin{array}{l}\text { No. } \\
\text { Bets }\end{array}$} & \multicolumn{7}{|c|}{ Uji Mikroorganisme Spesifik } \\
\hline & & $\begin{array}{c}\text { TAM } \\
\text { C }\end{array}$ & $\begin{array}{c}\text { TYM } \\
\text { C }\end{array}$ & $\begin{array}{c}\text { Escherichi } \\
\text { a coli }\end{array}$ & $\begin{array}{c}\text { Salmonell } \\
\text { a sp }\end{array}$ & $\begin{array}{c}\text { P.aeruginos } \\
a\end{array}$ & $\begin{array}{c}\text { S.aureu } \\
s\end{array}$ & $\begin{array}{l}\text { Shigell } \\
\text { a sp }\end{array}$ \\
\hline \multicolumn{2}{|c|}{ Syarat } & $\begin{array}{c}\leq 1000 \\
\mathrm{cfu} / \mathrm{m} \\
\mathrm{L}\end{array}$ & $\begin{array}{c}\leq 100 \\
\mathrm{cfu} / \mathrm{m} \\
\mathrm{L}\end{array}$ & Negatif & Negatif & Negatif & Negatif & Negatif \\
\hline 1 & LT144 & 5 & $<10$ & Negatif & Negatif & Negatif & Negatif & Negatif \\
\hline 2 & AB169 & $<10$ & 5 & Negatif & Negatif & Negatif & Negatif & Negatif \\
\hline 3 & $\mathrm{AB} 170$ & $<10$ & $<10$ & Negatif & Negatif & Negatif & Negatif & Negatif \\
\hline 4 & $\mathrm{AB} 171$ & 15 & $<10$ & Negatif & Negatif & Negatif & Negatif & Negatif \\
\hline 5 & GB101 & $<10$ & $<10$ & Negatif & Negatif & Negatif & Negatif & Negatif \\
\hline 6 & HB164 & $<10$ & $<10$ & Negatif & Negatif & Negatif & Negatif & Negatif \\
\hline 7 & IB155 & 10 & 30 & Negatif & Negatif & Negatif & Negatif & Negatif \\
\hline 8 & LB012 & $<10$ & 10 & Negatif & Negatif & Negatif & Negatif & Negatif \\
\hline 9 & CK031 & 5 & $<10$ & Negatif & Negatif & Negatif & Negatif & Negatif \\
\hline 10 & CK212 & $<10$ & $<10$ & Negatif & Negatif & Negatif & Negatif & Negatif \\
\hline 11 & DK127 & $<10$ & 10 & Negatif & Negatif & Negatif & Negatif & Negatif \\
\hline 12 & DK179 & 5 & $<10$ & Negatif & Negatif & Negatif & Negatif & Negatif \\
\hline
\end{tabular}

Berdasarkan aspek pengujian yang dilakukan terhadap 12 batch yang telah di produksi semua hasil yang didapatkan memenuhi syarat yang telah di tetapkan serta konsistensi proses olah terjaga. Selama periode 2020 - 2021 tercatat belum adanya perubahan proses, formula, penggunaan material, tidak adanya catatan complain, produk penarikan, maupun produk dikembalikan. Semua hasil persyaratan pada semua batch Vitamin D3 Syr memenuhi syarat dengan kategori baik hingga sangat baik.

Hal-hal yang terkait dengan mutu produk dikaji secara berkala, bertujuan untuk menemukan poin-poin yang perlu diperbaiki. Hal-hal yang perlu dikaji mempertimbangkan karakteristik kinerja dan produk, ditentukan oleh masing-masing perusahaan termasuk PT.Pyridam Farma Tbk. Dalam menjaga mutu produk Vitamin D3 Syr . Hasil pengkajian mutu produk dinilai, serta perlu tidaknya tindakan perbaikan dan tindakan pencegahan dipertimbangkan jika ada hasil yang tidak sesuai dalam berbagai aspek.

Tindakan perbaikan dan tindakan pencegahan dilakukan secara tepat waktu dan efektif berdasarkan aturan CAPA. Jika benar secara ilmiah, pengkajian mutu boleh dilakukan pada setiap kelompok produk seperti bahan padat, bahan cairan, obat disinfektan, dan lain-lain, dalam hal ini produk liquid Vitamin d3 Syr. Pemastian Mutu Produk merupakan salah satu penerapan aspek manajemen mutu yang diatur dalam CPOB. Secara umum, tujuan Pemastian Mutu Produk menurut WHO dan CPOB dalam industri farmasi adalah untuk meninjau mutu secara berkala dari semua produk farmasi dengan tujuan memastikan konsistensi proses serta kesesuaian semua aspek dan melihat tren jika ada perubahan yang dilakukan.

Menurut EMEA dan ICH Q7, PQR bertujuan meninjau active pharmaceutical ingredients (API) untuk memverifikasi konsistensi proses yang harus dilakukan setiap tahun serta mengevaluasi persiapan data produksi dan kontrol kualitas serta analisis data seperti tren, penyimpangan, serta variabilitas yang tidak terduga. Pemastian Mutu Produk 
berfungsi sebagai validasi berkelanjutan dan di sisi lain, data yang diperoleh merupakan prasyarat penting untuk melakukan perbaikan secara berkesinambungan.

Di Amerika Serikat, istilah Pemastian Mutu Produk dikenal dengan sebutan Annual Product Review (APR). Menurut FDA sebagaimana yang tertuang dalam code of Federal Regulations Title 21 Subbagian J bagian 211.180 poin e, tujuan Pemastian Mutu Produk (PMP) adalah untuk memastikan bahwa prosedur yang digunakan telah terverifikasi dan untuk mengkaji suatu kualitas obat. Standar mutu ini harus dikaji dan dievaluasi minimal 1 tahun sekali. Hal terpenting dalam menyusun Pemastian Mutu Produk bagi industri farmasi adalah untuk menetapkan aturan internal perusahaan dalam bentuk Standar Operasional Prosedur (SOP). Pembuatan dokumen Pemastian Mutu produk dalam penyusunanya berbeda -beda karena merupakan kebijakan masing-masing industri farmasi.

\section{Kesimpulan}

Hasil data pada penggunaan material bahan awal maupun bahan kemas primer \& sekunder tidak ada perubahan pabrik pembuat dan pemasok/ penyalur yang di gunakan untuk pengemasan produk. Formulasi yang di gunakan, pemantauan lingkungan, proses serta waktu pembuatan, tidak ada perubahan serta sesuai dengan yang telah di tetapkan dan memenuhi syarat. Penggujian secara fisika melalui pengujian organoleptic Memenuhi Syarat, tidak ada perubahan. Hasil untuk pengujian Viscositas Memenuhi Syarat dengan resume hasil 34,5 Cps (18,30-104,00) Cps, dari syarat 10 - 200 Cps. Terjadi kenaikan Viscositas pada Batch ke 2 (AB196) dan Batch ke3 (AB170).

Hasil Pengujian Berat Jenis Memenuhi Syarat pada resume hasil 1,06 (1,06 - 1,08). Hasil pengujian $\mathrm{pH} 5,44(5,25-5,76)$ syarat 4,5-6,5. Hasil pengujian Volume Terpindahkan Memenuhi Syarat $61.0(61,0-61,0)$ dengan hasil stabil pada setiap batch. Pengujian kadar Vitamin D3 Syr Memenuhi Syarat pada hasil 4,14 (3,68 - 4,62) pada setiap 5,00 mg dari syarat $(\mathbf{3 , 6 - 4 , 8}) \mathbf{m g}$. Pengujian kadar pengawet Memenuhi Syarat dengan hasil 4,89 $(5,26-5,37)$ pada setiap 5,00 mg dari syarat $(4,5-5,5) \mathrm{mg}$. Data hasil pengujian mikrobiologi pada setiap batch memenuhi syarat dari setiap pengujian TAMC, TYMC dan setiap bakteri uji yang di lakukan.

\section{Bibliografi.}

Amalia, Tisa. (2018). Tanggung Jawab Industri Farmasi Terhadap Penerapan Aturan Pemerintah Tentang Cpob. Jurnal Inkofar, 1(1).

Astuti, Reni. (2020). Manajemen Laboratorium yang Cerdas, Cermat, dan Selamat. CV Jejak (Jejak Publisher).

Dewi, Sofia Rhosma, \& Ners, S. Kep. (2015). Buku ajar keperawatan gerontik. Yogyakarta: Deepublish.

Handono, Kusworini, Kalim, Handono, Susianti, Hani, Wahono, Cesarius Singgih, Hasanah, Dian, Dewi, Elvira Sari, \& Rahman, Perdana Aditya. (2018). Vitamin D dan Autoimunitas. Universitas Brawijaya Press.

HR, H. Syamsunie Carsel. (2018). Metodologi Penelitian Kesehatan dan Pendidikan. Penebar Media Pustaka.

Irfiani, Nurliya, Pradana, Aditya Trias, \& Winantari, Agnes Nuniek. (2018). Hubungan Antar Faktor Penyebab Human Error Terhadap Jumlah Penyimpangan Produk Blister Di PT. XXX. Media Pharmaceutica Indonesiana, 2(2), 48-56.

Kodri, Husen, Una, Sayuti, \& Zaki, Muhammad. (2020). Pemberian Wewenang Dan Kewajiban Satuan Pengamanan Diuniversitas Islam Negeri Sulthan Thaha Saifuddin Jambi Ditinjau Dari Undang-Undang Nomor 2 Tahun 2002 Tentang Kepolisian Republik Indonesia. Jambi: UIN Sulthan Thaha Saifuddin Jambi. 
Novita Sari, Diana. (2021). Asuhan Kebidanan Continuity Of Care Pada Ny. N Masa Hamil Sampai Keluarga Berencana Di Pmb Lilis Sulistyowati, SST. Jawa Timur: Universitas Muhammadiyah Ponorogo.

Octaviani, Alisa Nur, \& Muhaida, Tia Septyani Nur. (2017). Praktik kerja profesi apoteker di pt ferron par pharmaceuticals periode bulan januari-februari tahun $2017=$ Internship at pt ferron par pharmaceuticals month period january february 2017.

Purwaningsih, Endang, Yuliwulandari, Rika, Soenyono, Soenyono, \& Santoso, Jarot Tri Bowo. (2019). Pengembangan Dan Perlindungan Obat/Jamu Tradisional Menuju Industri Obat Herbal Di Jawa Tengah Dan Jawa Timur. Jurnal Surya Kencana Dua: Dinamika Masalah Hukum Dan Keadilan, 6(1).

Rimahardika, Rosita, Subagio, Hertanto Wahyu, \& Wijayanti, Hartanti Sandi. (2017). Asupan vitamin $D$ dan paparan sinar matahari pada orang yang bekerja di dalam ruangan dan di luar ruangan. Semarang: Diponegoro University.

Sabarudin, Sabarudin, Suryani, Suryani, \& Nazir, Reni Amaliani. (2016). Evaluasi Mutu Pelayanan di Instalasi Farmasi RSUD Kabupaten Buton Utara berdasarkan Standar Pelayanan Minimal Kefarmasian. Pharmauho: Jurnal Farmasi, Sains, Dan Kesehatan, 1(2).

Santi, Maulida Annisa. (2015). Identifikasi Dan Evaluasi Pemenuhan Peraturan Perundang-Undangan Dan Persyaratan Lainnya Terkait K3 Di PT Kimia Farma (Persero) Tbk Plant Jakarta.

Saptarini, Dyah. (2019). Status Vitamin D pada Remaja Sehat Usia 15-18 Tahun di Kota Depok. Journal Of The Indonesian Medical Association, 69(2), 71-77.

Suhelayanti, Suhelayanti, Aziz, M. Ridwan, Sari, Dian Cita, Safitri, Meilani, Saputra, Syifa, Purba, Sukarman, Revida, Erika, Purba, Ramen A., Muharlisiani, Lusy Tunik, \& Simarmata, Janner. (2020). Manajemen Pendidikan. Yogyakarta: Yayasan Kita Menulis.

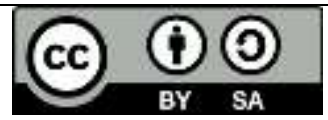

This work is licensed under a Creative Commons Attribution-ShareAlike 4.0 International License. 